Matematikai Közlemények

VII. kötet, 2019

doi:10.20312/dim.2019.07

\title{
PMSB és alkalmazása
}

\author{
Bán István \\ erdömérnök és alkalmazott matematikus \\ istvan.ban.dr@gmail.com
}

\begin{abstract}
ÖSSZEFOGLALÓ. A PMSB (Planned Method Selection by Bán) alapját a természetben megfigyelt állapotjellemzők értékeire vonatkozó axiómák adják. Az állapotjellemzők értékeinek halmazában a PMSB előre megtervezett módon azonossági részhalmazokat képez és ezekből a részhalmazokból választja ki egy adott érdek érvényesítésének legkedvezőbb lehetőségét. A PMSB a hétköznapi gyakorlatban széleskörüen használható.
\end{abstract}

\section{Bevezetés}

Az igen soktényezős és gyakran nem metrizálható tényezőket is tartalmazó bonyolult, de nem ismert hatásmechanizmusokkal rendelkező halmazokban egy adott szempont szerinti optimum keresés céljából dolgoztam ki a PMSB módszert.

\section{PMSB}

A természetben a PMSB matematikai modellezéshez az alábbi axiómákat figyeltem meg:

1. A természet az állapotjellemzőinek értékeivel írható le.

2. Az üres halmaz kitágítható (kiterjeszthetö) valós elemeket is tartalmazó halmazokká, amelyeket valós halmazoknak nevezzük.

3. Valós halmazokban az állapotjellemzők értékei állandóan változnak. Megjegyzés: A konstans állapotjellemzőt zéró értékváltozású állapotjellemzőnek tekintjük.

4. Az állapotjellemzők hatnak egymásra.

5. Adott állapotjellemzők átalakulhatnak más állapotjellemzőkké.

Az előző axiómák teszik lehetővé az állapotjellemzők értékei által definiált halmazoknak a vizsgálatát, különös tekintettel azok szerkezetére, tulajdonságaira és hatásmechanizmusára. Ezekben a halmazokban definiáljuk a kívánatos állapotjellemző értéket, amelyből származtatjuk az optimum fogalmát. Mindezek ismeretében nyílt lehetőség a PMSB matematikai modelljének megalkotására. Általánosan megfogalmazva és leegyszerüsítve a PMSB egy igen soktényezős bonyolult rendszerben egy adott érdek vagy elvárás kielégítése érdekében keresi meg a legkedvezőbb teljesíthetőséget, mint megoldást. A modell azonossági részhalmazok előre megtervezett módszer szerinti kiválasztásával keresi meg egy adott érdek érvényesítésének legkedvezőbb lehetőségét, mint megoldást. A módszer neve is ebből ered: Planned Method Selection by Bán kezdőbetűi PMSB. 


\section{Gyakorlati alkalmazás}

A PMSB gyakorlati felhasználásának megkönnyítése érdekében a matematikai modell szöveges számítástechnikai modelljét is elkészítettem.

Az alkalmazást nagymértékben elősegíti a számítástechnika rohamos fejlődése, elsősorban a gépek müveleti sebességének- és tárkapacitásának rohamos növekedésével valamint az adatbáziskezelő szoftverek ugrásszerü javulásával.

A PMSB gyakorlati felhasználása a mesterséges intelligenciában igen sokrétü, úgy mint az agrár-, gyógyászati, ipari- és az asztronautikai gyakorlatban. Jelentősebb alkalmazások a következők:

- a legjobb gyógyító terápia meghatározásának számítógépes modellje

- az ebola terápia számítógépes modellje

- génstruktúra analízis

- közgazdasági optimális stratégia meghatározása

- agrokémiai talajerőutánpótlás és technológiai szaktanácsadás.

- erdészeti fafajmegválasztás

- erdőállomány-fatömegbecslés

- GPS müködési jelazonosítás

- elektronikus adatrögzítés és olvasás

- univerzum képződmények keletkezése

- stb.

A PMSB részletes leírását és alkalmazását az alábbi két könyv tartalmazza: [1], [2].

\section{4. Összefoglalás}

Az állapotjellemzők értékeinek halmazában a PMSB előre megtervezett módon azonossági részhalmazokat képez és ezekből a részhalmazokból választja ki egy adott érdek érvényesítésének legkedvezőbb lehetőségét. A PMSB alkalmazható a gyógyászati-, mezőgazdasági-, erdészeti-, ipari és asztronautikai gyakorlatban.

\section{Irodalomjegyzék}

[1] István Bán, Mathematics, Language of the Universe. Rózsadomb Contact Kft. Budapest, 2018. p.132

[2] István Bán, PMSB in Artificial Intelligence. Rózsadomb Contact Kft. Budapest, 2019, p.175 